\begin{tabular}{c} 
Volume and Issues Obtainable at Center for Sustainability Research and Consultancy \\
Journal of Accounting and Finance in Emerging Economies \\
ISSN: 2519-0318 ISSN (E) 2518-8488 \\
Volume 6: Issue 1 March 2020 \\
¿SRᄃ \\
Journal homepage: www.publishing.globalcsrc.org/jafee \\
\hline
\end{tabular}

\title{
SMEs Exports are Influenced by Different Risk Factors: Empirical Study of Emerging Economy
}

\author{
${ }^{1}$ Safia Nosheen, ${ }^{2}$ Tahseen Mohsan Khan, ${ }^{3}$ Fazal-Ur- Rehman \\ ${ }^{1}$ University of Management and Technology, Lahore, Pakistan; safia.nosheen@ umt.edu.pk \\ ${ }^{2}$ Assistant Professor, Department of Finance, School of Business and Economics, University of Management and \\ Technology, Lahore, Pakistan; tahseen.khan@umt.edu.pk \\ ${ }^{3}$ MS scholar, University of Management and Technology, Lahore: 15002212004@umt.edu.pk
}

\begin{tabular}{l}
\multicolumn{1}{c}{ ARTICLE DETAILS } \\
\hline History \\
Revised format: February 2020 \\
Available Online: March 2020 \\
\\
\hline Keywords \\
Medical Instruments, Market Risk, \\
Operational Risk, Export \\
Refinance, SMEs
\end{tabular}

JEL Classification:

G14, G19, L81, L89

\begin{abstract}
The Study intent to identify the direct (indirect) risk factors that can influence the export of medical instruments from SMEs sector of Pakistan by using the time series monthly data sample for a period of fifteen years that is from FY 2003 to FY 2017. Empirically a strong long term relation between the export of medical instruments with operational risk, market risk, export refinance schemes and steel prices are proven by Johansen cointegration. Study also establishes a direct positive relation of operational risk and market risk with the export of medical instruments as a result of Vector Error Correction Model.
\end{abstract}

OPEN ACCESS

Corresponding author's email address: safia.nosheen@umt.edu.pk

Recommended citation: Nosheen, S., Khan, T. M. \& Rehman, F. U.,(2020). SMEs Exports are Influenced by Different Risk Factors: Empirical Study of Emerging Economy. Journal of Accounting and Finance in Emerging Economies, 6 (1), 201-218

DOI: $10.26710 /$ jafee.v6i1.1078

\section{Introduction}

Small and medium enterprises (SME) are considered as priority sector particularly for under developed and developing countries because of their contributory role in Gross Domestic Product, employment generation and poverty relief.SME also considered as the platform for creativity and innovation that stimulates national income by providing new business opportunities that leads to social stability. A study by International Finance Corporation (IFC) explains a positive correlation between the overall level of income of a country and the number of SMEs measured on a unit (per thousand) of population 1. 
The small and medium size enterprises are categorized on the basis of their number of employees and annual sales turnover. As explained by central bank of Pakistan in SME prudential regulation, a Small Enterprise (SE) is a business entity which meets both number of employees up to 50 and annual sales turnover to PKR 150 million and Medium Enterprise (ME) is a business entity that meets both number of employees up to 51-250 for manufacturing and service concerns and 51-100 for trading concerns and annual sales turnover above PKR 150 million and up to 800 million (State Bank of Pakistan, 2016). The increase in the level of financing to a sector is considered to be one of the sign of growth. In Pakistan over the period of three years from 2013 to 2016 the financing to SME sector increased by 9 percent that is from 284 billion to 400 billion. Development of SME can be a milestone for the growth of any economy. Therefore the central bank of Pakistan is keen to enhance the SME's contributory role and direct to enhance SME's existing 8 percent share to private sector to 17 percent and to increase the number of borrowers from existing 174000 to 500000 by 2020 ('Policy for Promotion of SME Finance State Bank of Pakistan', 2017). Further, to bring more entrepreneurs within the network, the central bank also relaxed the existing upper limit from PKR 75 million to PKR 125 million for retail exposure. This relaxation by central bank encourage the SME sector by providing the incentive for risk weighted assets calculation under Basel framework by relaxing the eligibility criteria of retail portfolio that is increased in the existing upper limit for retail exposure from PKR 75 million to PKR 125 million ('Policy for Promotion of SME Finance State Bank of Pakistan', 2017). The SMEs having their contributory role both as a part of formal and informal sectors and are distributed in three categories that include manufacturing, services and trading.

Illiteracy is one of the basics issue in terms of basic education of the under-develop and developing countries and from time to time these countries used to address this issue. But in these countries so called illiterate people are observed to be more skilled than literate people and having major contributory roles in SME sector. The informal sector having major contributory role as compare to formal sector because this sector not only provide the opportunities but also develop and utilize the skills of illiterate people. Finding skilled people is one of the major global issue and most of the developed countries hire skilled people from under-develop and developing countries. Major industrial and other SMEs facing similar problems in term of finding skill labor a study by (Karadag, 2016) support this argument "SMEs are currently going through a tough test of survival capabilities, mainly due to tightening credit conditions, difficulties in finding new customers and shortage of skilled labor". Further, particularly in under-develop and developing countries child labor is one of the core issues. Where poor parents not even able to meet the food need of their children, no choice is left for them except to send their children for work. These children start their careers with SME sectors and grow themselves with this sector. Over the period these children not only start spending comfortable life but some of them also become national leading entrepreneur and hire number of high degree managers. Over last two or three decays the economic contributory role of women in society has achieved a new height. In developing countries number of women running their business as successful entrepreneur with creativity and innovation is increasing. SMEs are ranged as tier 1 among industries being supplier to large industry.

SMEs having its' global economic significance for all type of economics and play its' role for economic growth by providing decent jobs in mainstream economics, overcoming a large deficit between rich and poor revenue by providing opportunities for poorer survival in under-develop and developing economies. Social economy deals with the factors influenced by the behavior of people or in other words having awareness about the need of people. In present era the basic needs of humans are not limited to the extent of food, cloth and shelter but it also includes health, education and employment. The resources of underdevelop and developing countries not having cushion even to meet the basic needs of their people. In such countries SMEs play vital contributory role not only by providing employment opportunities but also developing low cost products to meet their basic needs. SMEs solely cannot contribute to economy without state support and direction to the entrepreneurs. A study by (Taiwo, Ayodeji and Bako, 2012) states that "the most common constraints hindering small and medium scale business growth in Nigeria 
are lack of financial support, poor management, corruption, lack of training and experience, poor infrastructure, insufficient profits, and low demand for product and services". SMEs as a part of private sector develop speedier and play a significance role as paramount way to coup poverty and inequality by integrating into global economy through economic liberalization, deregulation and democratization. In agriculture based economies, SMEs significantly play its' role by the transition of agriculture-led economies by involving processing activities. The processing activities convert agriculture-led into finish product through industrial ones that provide opportunities to generate more employment, additional resource of revenue and enhance the development process. The economic significance of SMEs is not only limited to under-develop and developing countries but this sector also have significant role for the main stream economy development.

Obstacles are considered to be a phenomenal part of every business and its growth. The key obstacles are observed in the growth of SMEs in under-develop and developing economies are energy crisis, taxation problems, labor issues, creativity, innovation, precise policy and regulatory reforms etc. Further, the SMEs that can play global role facing additional constrains in term of law and order situation images as key issue. A study by(Wang, 2016) as the results of the statistical analysis highlight, "the five most significant obstacles SMEs face are access to finance, tax rate, competition, electricity and political instability". There are countries having rich resources that provide opportunities to the entrepreneurs to start new business and globally introduce their products. Similar in under-develop and developing countries a number of entrepreneurs stop manufacturing their traditional handmade unique products. Because they have no access to product demand markets, financial constraints and have no support from State and/or financial institutions. A study by (Wang, 2016)highlights "Among the five obstacles, access to finance appears to be the biggest obstacle, followed by competition". SMEs sector even a part of formal sector being borrower face problem in exchange of information with lender and bear high cost because of small and medium size associated risk not only face in developing economies but also in main stream economies. A study also highlight asymmetric information as a factor by (Beck, 2007)conclude that "transaction costs and asymmetric information between borrower and lender are the driving factors explaining the limited access to external finance by many SMEs in developing as well as developed economies". Skill labor is one of the global problems, in case formal sector education became the hurdle for the illiterate skill person.

Pakistan is ranked 68th largest exporting country in the world2and the key exporting products from Pakistan includes Rice, Mangoes, Furniture, Leather, Sports, Cutlery and Surgical etc. Whereas the country consists of four provinces that include Punjab, Singh, Khyber Pakhtunkhwa and Baluchistan. Punjab is considered to be the largest province in terms of population or we can say in this province almost about $50 \%$ of country population is residing, the total population of Punjab equals to 110.01 million against the total population of country that is equal 207.77 million in 2017 . As our study is focusing on the export of medical surgical instruments and we have chosen Punjab province as our study area because Punjab has major democratic medical surgical instruments export shares that is equal to about $90 \%$ of total country medical surgical instruments exports. Pakistan is facing high degree of trade deficit that is equal to $\$ 26.57$ billion during 2017 , the country having export level equal to $\$ 21.94$ billion as compared to the import level equal to $\$ 48.51$ billion. The alarming sign is continuity of increasing trend in the level of trade deficit since last four years. Over four years the trade deficit increase by $32.97 \%$ from $\$ 16.5$ billion to $\$ 21.94$ billion. Medical instruments and metal allied products not having major share of country exports but the most significant role of this industry is their products are every global market demanding products and existing industry having export share equal to $80 \%-90 \%$ of their total production. Different initiatives are taken to enhance the export level by State and/or its' associate organizations also include surgical sector as promising one. In order to minimize the trade deficit, the country's' Central bank also initiate by introducing new refinance facilities at cheap rate for certain priority SME sectors that include IT, furniture, surgical goods, dates processing, gems \& jewelry, leather 
industry, fruits, vegetables \& food processing and packaging, printing \& packaging to encourage the exporters. Further, to overcome the deficit level the significance of SME sector is also more highlighted. "Pakistan Stock Exchange has proposed 20 percent corporate income tax rate for small and medium size listed companies to promote entrepreneurship"3. The significant role of SMEs are explained in SME Observe as "In Pakistan, around 99\% of economic establishments are SMEs that collectively contribute an estimated $40 \%$ to GDP and over $40 \%$ to the exports"(SMEDA., 2017). Pakistan is considered to be an agriculture based country with agricultural base contributory industrial role as well; in terms of area the agricultural land is $35.2 \%$ of total land that is $770,875 \mathrm{sq} \mathrm{km} 4$. Pakistan is engaged in the export of different commodities that include food group, textile group, and petroleum group etc. The textile sector that is based on agriculture having leading exports from country role across all the groups as per the information provide by central bank of country5, the details can be evident from under mention table-1.

Table-1: Export of Commodity from Pakistan

\begin{tabular}{|l|l|l|}
\hline COMMODITY & $\begin{array}{l}\text { FY 2016 } \\
\text { (Thousand US\$) }\end{array}$ & $\begin{array}{l}\text { FY 2017 } \\
\text { (Thousand US\$) }\end{array}$ \\
\hline Food Group & $3,722,489$ & $3,611,952$ \\
\hline Textile Group & $12,756,277$ & $12,453,506$ \\
\hline $\begin{array}{l}\text { Petroleum } \\
\text { Group }\end{array}$ & 450,201 & 410,718 \\
\hline $\begin{array}{l}\text { Other } \\
\text { Manufacture }\end{array}$ & $3,804,506$ & $3,654,627$ \\
\hline $\begin{array}{l}\text { TOTAL } \\
\text { EXPORTS }\end{array}$ & $21,971,996$ & $21,938,000$ \\
\hline
\end{tabular}

The medical instruments value US\$ 400.85 million6 export from Pakistan in 2015-2016 that include $89.31 \%$ export share from Punjab Province with the contributory role equal to US\$ 358 million as compared to $\$ 339$ million in 2014-20157. The trend of medical instrument export over study interval can be viewed in figure-1.

Figure-1: Medical Instruments Export (US \$ in 000) Over 2003-2017

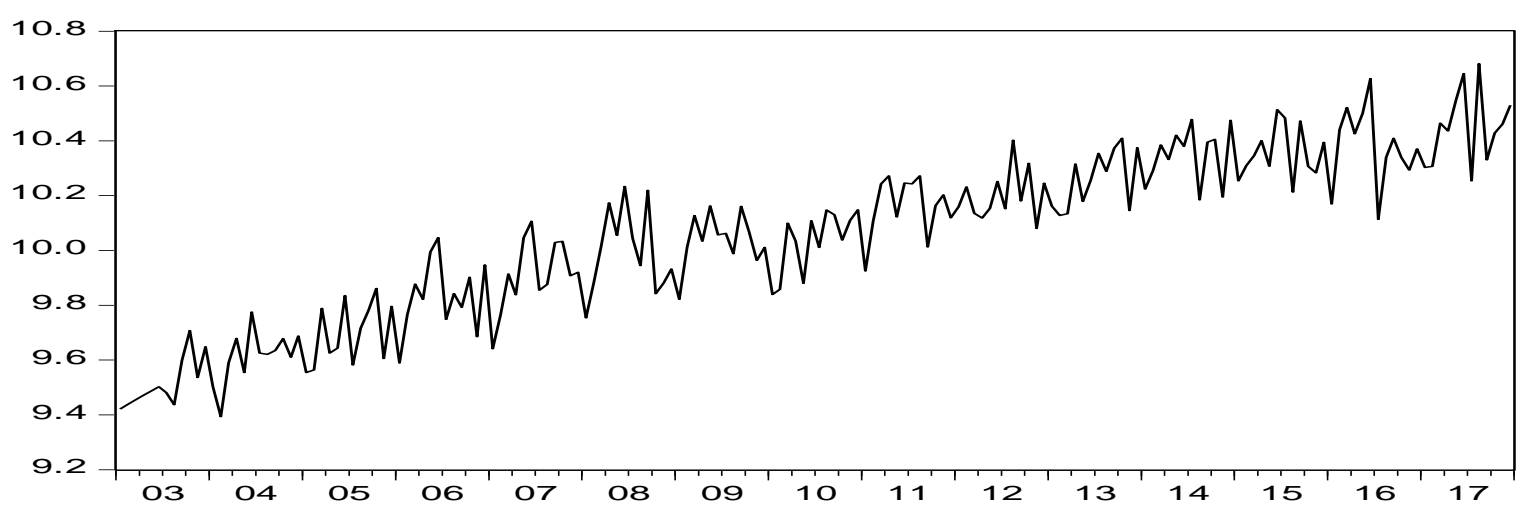

The manufacturing of surgical instruments in fact in this region start at the shot of century when the demand of medical instruments generate by American Mission hospital of Sialkot and same successfully

3http://www.pkrevenue.com/inland-revenue/budget-proposals-20172018-psx-recommends-20pc-corporate-rate-forsme-listed-companies/

4 https://www.cia.gov/library/publications/the-world-factbook/geos/pk.html

5http://www.sbp.org.pk/stats/survey/index.asp

6http://www.sbp.org.pk/ecodata/Export_Receipts_by_Commodity.pdfenhence

7 Data collected from the sources of Surgical instrument Manufacturers Association of Pakistan (SIMAP) 
reproduce by local craft workers. In 1930 the medical instruments SME cluster start exporting their instruments to Egypt and Afghanistan. Further during Second World War they establish themselves as medical instruments manufacturing industry and play vital role to meet the demand of Indian and Allied forces. In 1941 the British Government takes the initiative to establish the Metal Industries Development Center to facilitate the local industry. Since that period to date Sialkot and its surrounding cities that include Gujarat, Gujranwala, Wazirabad etc. are engaged in the manufacturing of metal products include medical instruments, personal and saloon beauty care goods, hospital metal furniture, Hollowware etc.

SME sector businesses are engaged in three dimensions that include trading, services and manufacturing. We initiate to focus on the role of SME's medical instruments related manufacturing cluster and analyze the factors that have possible influence on the exports of medical instruments from the largest province of country that has major democratic export oriented manufacturing concerns. Sialkot is one of the famous city of the country and globally known for the world best quality sports goods and medical instruments. The world market size of surgical goods is estimated around US $\$ 30$ billion. In Pakistan there are about 3600 members firms register with Surgical Association.

Pakistan was established as an independent State on August 14, 1947 and inherited only 34 industries that include 17 surgical industries. Punjab being the largest province of country having major dependence on agrarian economy and require to develop more industries to boost economic growth. Industrial Planning Committee was setup in 1948. The committee efforts resultants to build 310 new industries in Punjab that include a major part of surgical sector. In 2004-2005 the survey of large, medium and small selected sectors covers the total number of units equal to 18006 and in 2010 small scale and cottage level industrial units report decrease by 178578 .

Common Facility Centre (CFC)9 initiated by the State to facilitate the manufacturers by establishing cluster development program (CDP). CDP works as different business stakeholder network with the objective to boost economic activity by providing low cost manufacturing opportunity that also create employement opperunities. Futher, Small Medium Enterprise Development Authority(SMEDA)also initiate to promote SME sector by providing awareness about modern technology, global markets, human resource skill programs that include international certifications and global regulations etc. State from time to time also takes initiative to promote export and do address social issues. A study by Ghulam Mustafa (2011)10states "Federal Government is taking initiatives to boost surgical industry of Punjab and released Rs. 30 million issued out of export development program, these steps of federal government helped the surgical industry in innovation and growth of surgical export. Despite this effort, they also issue Rs. 28 million to make surgical industry free from child labor and Rs. 1.7 million for cluster development program in Punjab". Another state own entity Punjab Small Industrial Corporation (PSIC)11 developed different projects that include Product Development Centre for sports goods, Cluster Development Centre for metallurgy, dies, casting and agriculture implements etc. Similar to this, Surgical Instrument Manufacturers Association of Pakistan (SIMAP) with the collaboration of Pakistan Council of Scientific and Industrial Research (PCSIR)12initiate common facility centers in Punjab. These associations and centers automatically help the industry by addressing the gaps in different sectors by introducing research, development and innovations.

\section{Literature Review}

8http://www.doi.punjab.gov.pk/history

9 It is one place shop for manufacturers or exporters in converting raw material to finished goods.

10 Ex-Chairman of Surgical instrument manufacturing association of Pakistan

$11 \mathrm{It}$ is an organization to develop with the aim to strong industrial estate in different regions of Punjab such as small industrial estate of Sialkot.

12 It is an organization developed under societies act in 1953 with an aim to promote science and technology in industries of Punjab. 
The exports and imports play an important role to meet the shortfall of skills, services and goods across countries that help in there development and growth. The key challenge, which countries face, is to create the equilibrium between exports and imports. Countries having trade deficit more emphasize to increase their level of export and take different measures to encourage the export oriented sectors. The medical instruments manufacturing industry in Pakistan engage in the export of about $80 \%-90 \%$ of its production13and can play a vital role by increasing its production capacity. We are focusing on the different factors and initiate to analyze the impact of these factors on the export of the medical instruments from country. One of the factors is the way government provide support to different areas in the shape of different incentives schemes to the exporters.

\subsection{Export Refinance Scheme}

The State plays an important role by providing different incentive schemes for exporters with the objective to generate foreign currency and to boost economic activities. The incentives to the exporters include cheap financing, reliefs, tax benefits etc. In Pakistan the Ministry of Commerce (MoC) has fix mark-up rate of $1.5 \%$ on Export Finance Scheme (EFS) on selected export sectors that include surgical sector, a source at MoC told Customs Today, adding that Ad-Hoc relief @ 3\% of Free on Board to offset the impact of higher cost of utilities for Pakistani exporters in surgical sector along with others has been granted.14The State Bank of Pakistan (SBP) issue loans to exporters or manufacturer cum exporter to boost export and economic development. Further also ensures supply of sufficient financing to medical industry or any other value added industry at competitive rates and these policies are continuously reviewed to achieve optimal objectives. From time to time SBP uses to take steps to promote the export oriented industries by providing financing and/or refinancing schemes for continuity in growth and their smooth operations. Number of studies supports this argument i.e.(Wang et al., 2017)states that "export promotion program developed by government enhance the export performance of the country". (Enad et al., 2017) indicate that "different countries establish various export promotion program in such way that it positively influence the export performance of economy which automatically strengthens the economy through bringing international currency in the country". (Ali and Shamsuddoha, 2004) find that "export promotion program hasimpact on the firm performance of firm while it indirectly effects the determinant of firms such as firms' export knowledge and manager behavior in dealing export and all these collectively influence the performance of the firm". (Kim-Soon, Ahmad and Pei Shy, 2016) argues that "export promotion is given for the purpose of foreign trade delegation which enhance firms' product quality and gaining reputation and in result export promotion increase the sale with profit". (Haddoud, Jones and Newbery, 2017)argues that "all kinds of informational and experiential promotion programs improve all relationships of Small and Medium Enterprises while it is helpful to build strong relationship with foreign buyers". (Ahmad, 2015) indicates "a direct relation between the levels of export is to incentives". There are also numbers of studies that do not support arguments. (Geldres-Weiss and Carrasco-Roa, 2016) examine "the impact of export promotion program on sales performance of the Chile firms' and analysis established on the user and non-user of export promotion program through longitudinal data but they did not find any significant difference in the performance of sales". The detail of export refinance facility availed by medical industry over study interval can be viewed in figure- 2 .

Figure-2: Export Refinance Avail by Medical Instrument Industry in Punjab (US\$ 000) Over 2003-2017

13http://www.customstoday.com.pk/ministry-of-commerce-takes-measures-to-enhance-exports-of-surgicalinstruments/

14http://www.customstoday.com.pk/ministry-of-commerce-takes-measures-to-enhance-exports-of-surgicalinstruments/export

206 
LNF IN

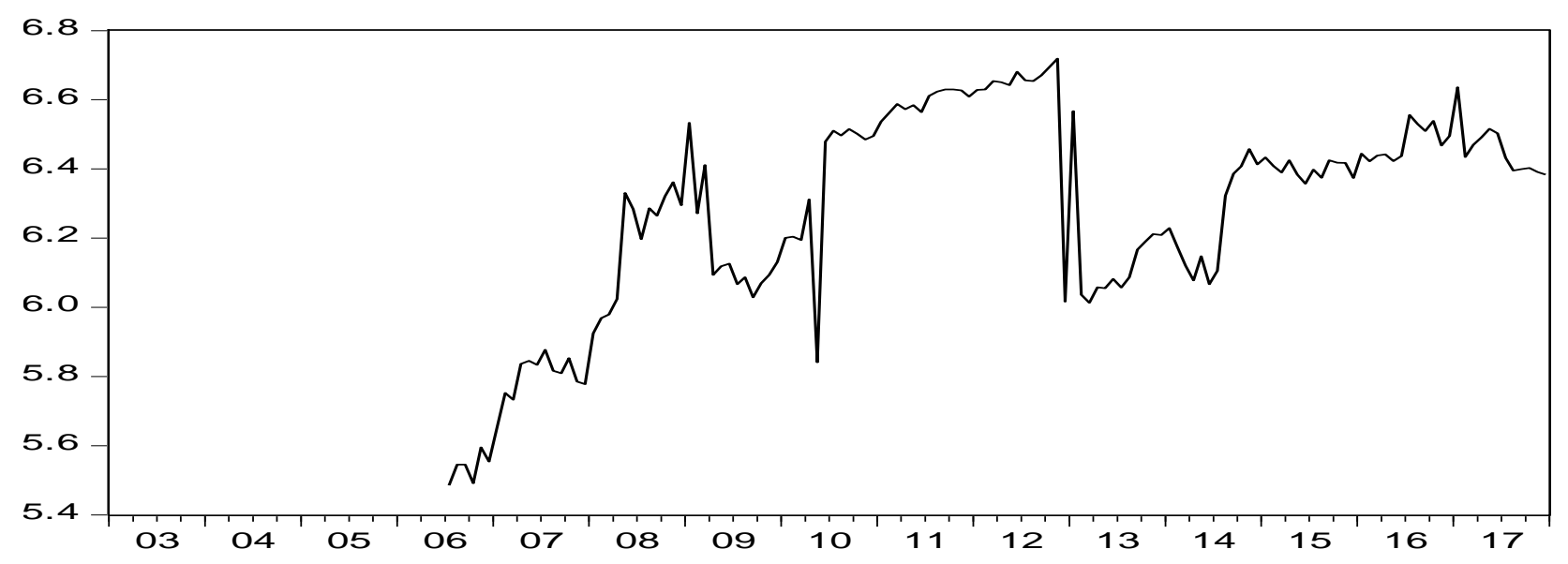

\subsection{Operational Risk}

Operational risk deals with the possible loss or failure due to breakdown of system, procedure, error or fraud etc. Pakistani industry facing big challenge in terms of electricity load shedding, there are alternative ways to meet this challenge but they are not cost effective. Secondly, it may not be possible for small industry to have backup solutions. We have also considered electricity as proxy for operational risk and as a factor that can influence the export of the medical instruments. To meet this requirement, we have only considered hydro production generation part because the electricity requirement of Punjab is captured by hydro.

\subsection{Electricity Production}

The main sources of electricity generation in Pakistan are hydro and thermal powers, whereas other generation sources with a little role include solar, coal and wind. The electricity generation in country is consumed by industry, agriculture and residential areas and to make the electricity price cost effective, a proportion between the different sources is to be maintained. In fact it is not possible to solely relay on thermal power because of its very high cost, to make it cost effective by maintaining the proportion with cheap sources country have to face load shortage and load shedding directly affect the industrial production and agriculture. Further, the electricity break down causes an additional cost to the product due to material wastage, labor cost without work, delay in delivery etc. There are number of studies that support the argument in term of electricity generation and industrial production and/or exports. (Bashir, Nasim and Ismail, 2016) analyze that "electricity plays an important role in the growth of developing countries such as Pakistan because electricity production ensures optimum use of natural resources". Energy generation is considered an important source to drive the economic vehicle. But Pakistan is still facing a gap between demand and supply of energy due to which the industrial front is badly affected. An article in daily Newspaper by (Khalida Parveen 2016)15 highlight that "New units of production could not be opened, even that established units cannot run smoothly due to less supply of electricity". Further, due to shortage of electricity and gas major export oriented industries like textile and knitwear facing decline in its production. (Acute et al., 2014) investigate "the relationship between energy consumption, trade and GDP and find out that in short run, relationship exist between energy consumption and export and energy consumption and export while in long run, relationship exist between energy and GDP but indirectly relationship exist between energy and export. (Javid et al., 2012) indicates a unidirectional causal relationship from electricity consumption to economic growth which implies that electricity is a limiting factor to economic growth and hence, shocks to electricity supply will have a negative impact on economic growth". The detail of hydro production over study interval can be viewed in figure-3.

Figure-3

Hydro Electricity Production(Billion Kilowatt Hours) 
Over 2003-2017

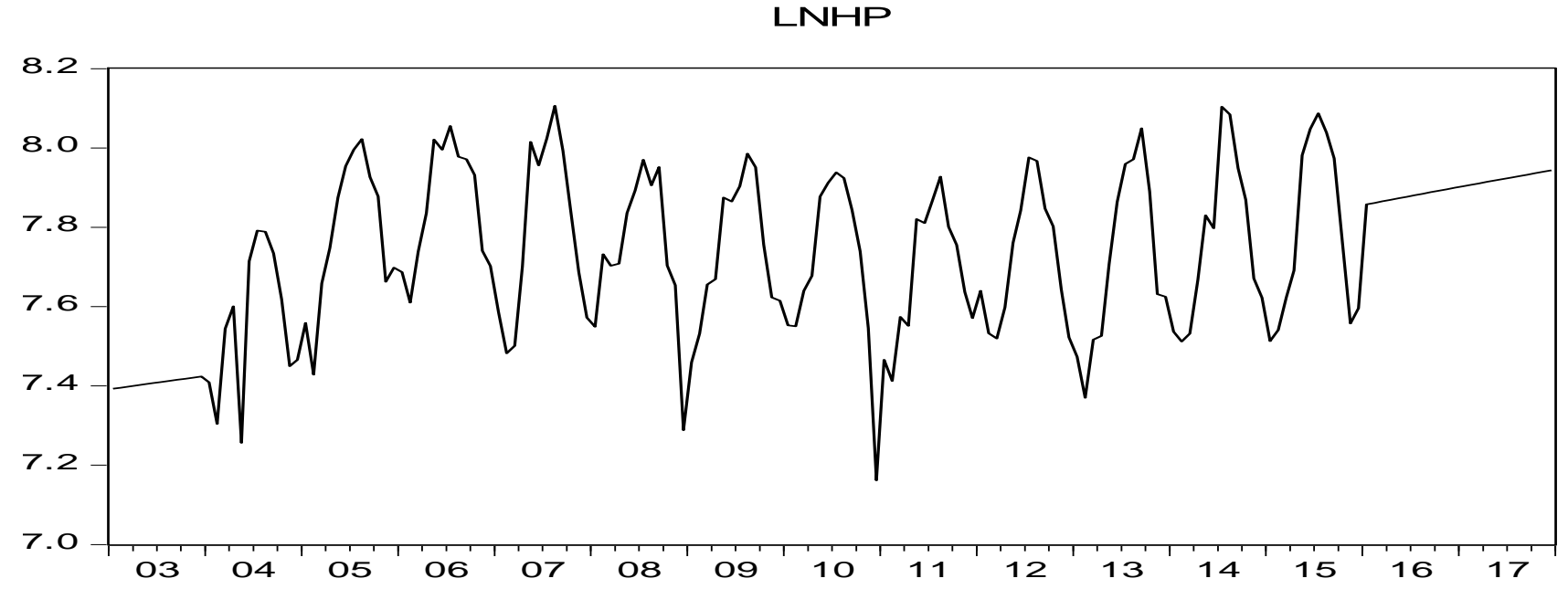

\subsection{Market Risk}

Market risk deals with possible loss influence due to volatility in exchange rate and interest rate. We have also considered interest rate and exchange rate as proxy for market risk and as the factors that can influence the export of the medical instruments.

\subsection{Interest Rates}

The interest rate is considered to be the price of credit availed through any source and any change in interest rate directly affect the cost of product. Interest rates have an impact on financing at any stage. The most popular Fed rates are driven as monitory policy decision by Fed managers considering to fostering maximum employment and price control. Interest rate is considered as the part of the loan that is paid to the financial institutions as charging amount for the use of money and also consider as a key factor to set the level of export in an economy. Higher interest rate lowers the net export because higher interest rates drive the exchange rate upward while investor wants to buy domestic currency and receive higher interest rate and thus lower down the export. In this context interest rate impacts on different variables, a number of studies are conducted, few of them are discussed here. A study findings by (Saraç and Karagöz, 2016)evident differently "no evidence that higher interest rates cause to a weakening of exchange rate". Technically, if the interest rate is low than the export of country will automatically boost (Matthew John)16, it means interest rate has a direct impact on product cost that provide more negotiation cushion and business confidence. (Bikker and Vervliet, 2018)indicate that "a low interest rate environment indeed impairs bank performance and compresses net interest margins". High interest rates normally discourage investor to take out high risky projects (Raah Financials)17.Interest rate has impact on both domestic and international level, when interest increases it means that exporters will get loan at higher rates which lead to higher production cost and thus lead to high sales price, in result export of country reduce (AnkitKakadiya)18. James Sackey (2015)19describes when US interest rates are higher than US dollar will be expensive means that value of US dollar appreciated as compared to the currency of other countries thus country will experience the growth in imports and decline in exports. To meet the study requirement we have chosen the return on Government of Pakistan Bond's as proxy for interest rates and check its' influence on the export of surgical instruments from Pakistan. The variation in the interest rates over study interval can be viewed from figure-4.

Figure-4: Interest Rate Variation in Percentage Over 2003-2017

16https://www.quora.com/How-does-interest-rate-affect-net-exports

17https://www.quora.com/Why-does-a-high-rate-of-interest-lower-net-exports-Please-answer-in-detail 18https://www.quora.com/Why-does-a-high-rate-of-interest-lower-net-exports-Please-answer-in-detail 19https://www.linkedin.com/pulse/how-interest-rates-affect-international-trade-james-sackey 


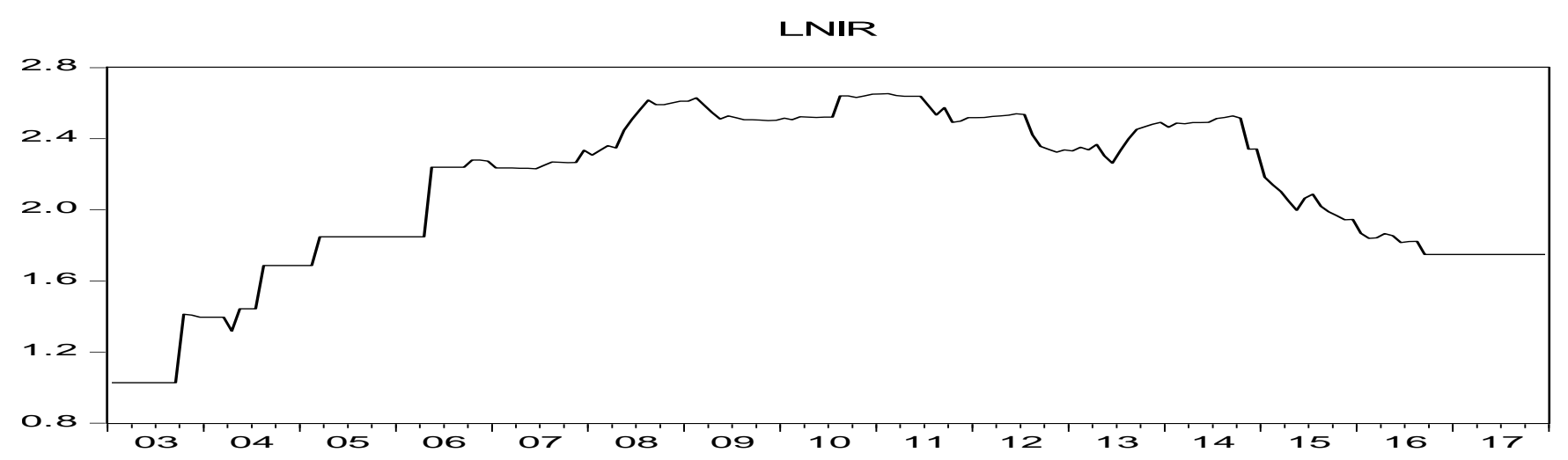

\subsection{Foreign Currency}

The exports of medical intrument's major part is in US dollar andthe dominance of US dollar for global trade is still having significant role. In this context of US\$ impacts on different variables, anumber of studies are conducted and few of them are discussed here.A study by James Sackey (2015) 20describes "a direct relation between US dollar exchange rate with imports and indirect relation with the exports". (Fang, WenShwo, Lai, YiHao and Miller, 2006) conduct a study on eight Asian countries investigate "depreciation encourages exports, as expected, for most countries, but its contribution to export growth is weak. Exchange rate risk contributes to export growth in Malaysia and the Philippines, leading to positive net effects. Exchange rate risk generates a negative effect for six of the countries, resulting in a negative net effect in Indonesia, Japan, Singapore, and Taiwan and a zero net effect in Korea and Thailand". Aqeel and Nishat (2006) investigate "the long run relationship between exchange rate volatility and export performance in Pakistan". (Haque and Kemal, 2006) evaluate impact of export financing and rebate/refund schemes on export performance and analysis shows that, "over the long run, the export financing scheme had a negative effect on exports while the rebate/refund scheme affected exports insignificantly". Other factor that can influence the exchange rates is the phenomena of demand and supply, although central banks of the countries keep their eyes on the movement and make necessary corrections when require in order to maintain the level of country foreign reserves. The countries who switched from fixed to flexible exchange rate system due to higher degree of variability associated with flexible exchange rate systems. The existing literature in the light of exchange rate volatility reflecting mix results that is it may have negative, positive and no impact on investments. Here, we can say its' not necessary that any change in exchange rate having direct effect on the price of product. Therefore, we have chosen US \$ as a factor and check its' influence on the export of medical instruments from Pakistan.The variation in US dollar over study interval can be viewed in figure-5.

Figure-5: Dollar Exchange Rate Variation against PKR Over 2003-2017

LNDR

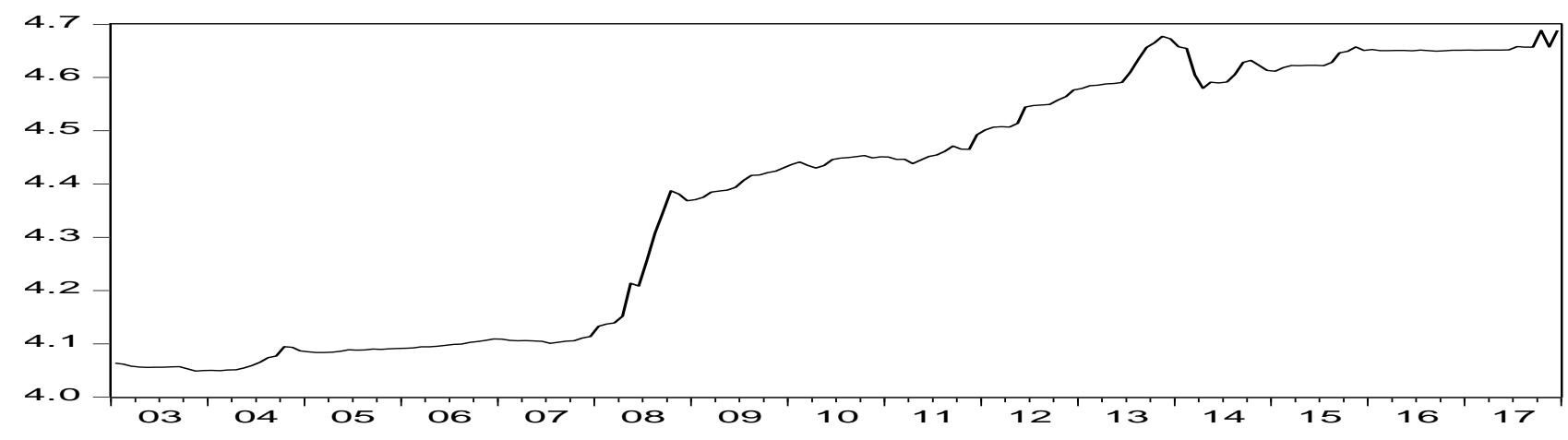




\subsection{Steel and Gold Price (Raw Materials for the surgical industry)}

For the manufacturing of medical instruments the raw material is the key factor that influence the finish good in terms of quality and price etc. Raw material used in the manufacturing of medical instruments is imported and the price of raw material can be influenced due demand and supply, interest and exchange rates etc. The medical instruments are used for human welfare and it is the demand of modern era to have the surety to be up to health standards by applying sensitive checks. Steel is the key material used for the manufacturing of sensitive area instruments. The modernization play vital role by introducing wide range of steel with cost effectiveness. Manufacturing of metal medical instruments and allied is considered to be the most innovative area according to the need of mankind. Now the metal products are also going to be replaced by other materials like rubber, wood, ivory etc. But in accordance to the present era sensitive measures the iron, cobalt, chromium, titanium, and tantalum are proven to be most reliable and safe particularly for medical instruments and implant. As because of limited use of gold for plating of medical instruments gold is considered an optional part for manufacturing the medical instruments. .And for few special treatments like for Rheumatoid Arthritis gold make medical rings are used. Further, (Warren and Pearson, 2012) also evident that "a relationship exists between gold and prices of all commodities such as steel, iron etc. A study by (George Jackson 1938) establish a relation between gold and other commodities "the increase in the prices of Gold, it will automatically and immediately increase the prices of all other commodities". Usually any additional cost to product either due price pressure or any other associate risk add to final product, but sometime due stiff competition such additional costs have to adjust against profit margin or to face loss. A survey of European chief executive officers and purchasing officers revealed that raw material cost hassignificant impact on the success of the European business performance. Factors that influence the raw material supply to business may include population growth, natural disasters, and political instability.

Therefore, we have also considered raw materials that include steel and gold as factors that can influence the export of the medical instruments. The variations in price of raw material is due to either material shortage, interest rate, exchange rate etc. influence adversely the operation and profit margins of the business concerns or add cost to the product. The price of products can also influence due to political instability, change in economic conditions, energy cost and/or load shedding, transportation cost or any other cost input. In short, we can say that an increase in cost of product has an adverse effect on the business concern. In order to mitigate such risks, the business concerns take different measures like hedging, by incorporating causes related to cost inputs as a part of agreements between buyers and sellers. "Companies must put in strong defenses against increases in raw material prices if they want to survive the global competition. It is also vital to take out risk by harmonizing purchase and sale prices, said Richard McIntosh, UK Managing Director of INVERTO21."Companies are not using the full range of strategies available to them to defend against price increases and manage both costs and supply chain risk," continued McIntosh.

The variation in the prices of steel and gold over the study interval can be viewed in figure- $6 \& 7$. 


\section{Figure-6}

Steel Prices Variation (Metric per Ton)Over 2003-2017
Ounce) Over 2003-2017

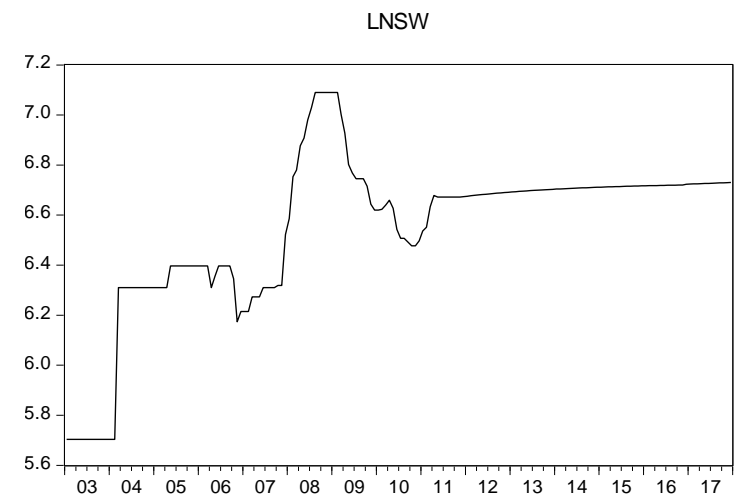

\section{Figure-7}

Gold Prices Variation (Per Tory

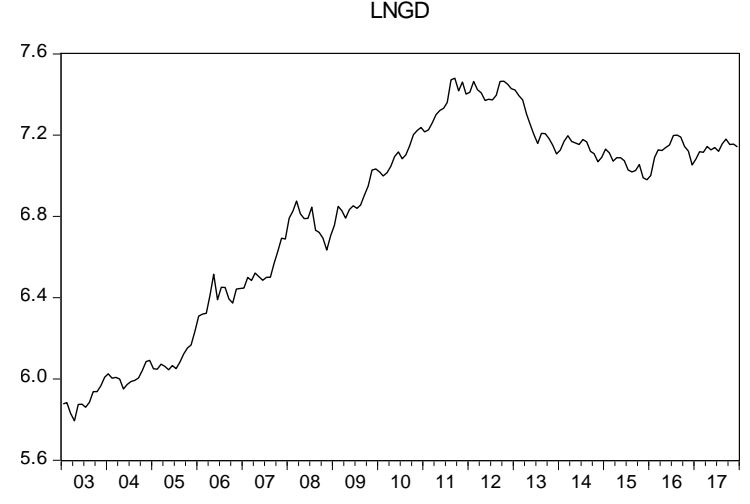

The existing literature highlight country export levels significance in relation to enhancing the level of country foreign reserves, declining unemployment, industrial development, creativity, innovation, introduction to new technology and economic stability. Since almost two to three decades Pakistan due to its' strategic location and poor governance facing the multiple challenges particularly relate to law and order, energy crises, taxation problems, labor issues, precise policy and regulatory reforms. Pakistan being emerging economy facing instability due to cross boarder interference that distress internal law and order conditions, this instability stretch serious economic damage to country in term of shake in the confidence of foreign investors due to that country loss the opportunity of foreign investments and of foreign buyers as well. Further, country poor governance do not take serious measures to overcome country weaknesses like to generate cheap energy, taxation and regulatory reforms and control over fluctuation in interest and the exchange rates etc.

We find the influence of these factors as a gap to existing literature in term of the exports of the country. This study initiate to analyze the influence of multiple factors that include export refinance facilities, hydro electricity generation (use as proxy for operational risk), interest rate and dollar exchange rate (both use as proxy for market risk), steel wire prices and gold prices on the export of surgical instruments from Pakistan. The medical instruments industry is chosen being as a part of SMEs sector. Further, Punjab being biggest province of Pakistanis chosen as study sample because of its export contributory role that is equal to about $90 \%$ of total medical instruments exports from country.

This study initiates to provide the awareness among the surgical industry stakeholders to have understanding about the key factor that can have influence to the exports of medical instruments from Pakistan.

\section{Theoretical Framework}

The products are exported from the country under assigned HS codes to make it transparent and for medical instruments export the assigned HS codes are 9018, 9019, 9020, 9021, 9022, 9025, and 1110. State Bank of Pakistan ensures supply of sufficient financing to the surgical industry at competitive rates and these policies are continuously reviewed to achieve optimization objectives and results having consistency with studies by Wang et al (2017), Enad et al (2017) and Geldres-Weiss (2016). The energy within country is generated by different ways that include solar energy generation, hydro power generation, thermal power generation and wind power generation etc. the current study focuses on electricity generation from Gujranwala Electricity Power Company (GEPCO)because it meets the energy requirement of the area that cover the surgical instruments industry of Punjab. The interestrate within country has an influence on both domestic and international markets. Theoretically interest rate has an inverse relationship with country exports, whereas dollar has its significance as dominant currency in 
Pakistan. A study by Bashir et al (2016), Shahbaz (2015) support this argument "dollar is the main currency used in the export of Punjabi medical goods to the international market". Steel is used as key raw material in the manufacturing process of medical instruments and its' behavior is supported by disappointment theory. Gold creates attraction in the surgical instruments. The sensitive and/or specific surgical scissors rings are made of gold rings; however, it is optional in the manufacturing process.

\section{Conceptual Framework}

The manufacturing process of medical surgical instruments that consist of different stages as highlighted above and the factors are consider to be analyzed in our study having great importance due to their influence. Export refinance is provided to faciliate exporters in pre and post manufacturing process under the export promotion program, possible breakdown of hydro electricity production do hasdirect influence on manufacturers. Cost of product base on imported raw materials requires to mitigate the financial risks that include interest and exchange rate variation risk.

Figure 8: Conceptual Framework

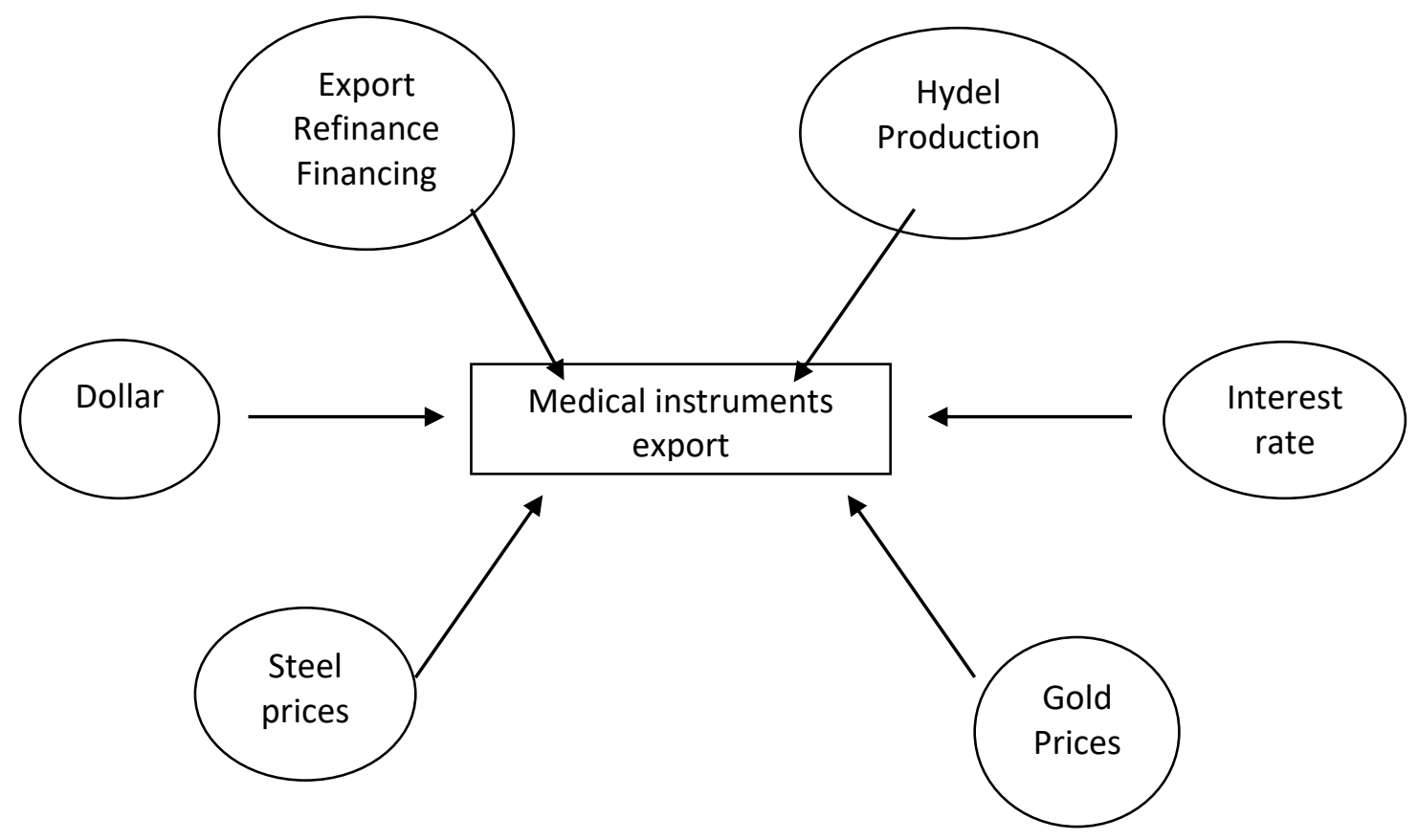

\section{Data and Methodology}

\subsection{Data Description}

The data is extracted from multiple sources that include State Bank of Pakistan (SBP), Ministry of Commerce, Islamabad, Pakistan (MOC), World Bank, Trading Economics, and Trade Statistics for International Business Development (Trade Map) and is classified as time series of required monthly frequency variables over the period of fifteen years that is from FY 2003 to FY 2017. Study is limited to analyze the influence of export refinance scheme, hydro electricity production, interest rate, dollar exchange rate, steel prices and gold prices on the export of medical surgical instruments from Punjab that is largest province of country with about $90 \%$ of medical instruments export share.

\subsection{Research Objective and Hypothesis Construction}

\subsubsection{Research Objective}

We intent our research with the objective to identify the analysis of the factors that can increase (decrease) the export of medical instruments. The analysis took into account how export refinance scheme, hydro electricity production, interest rate, dollar exchange rate, steel prices and gold prices influence with the export of medical instruments in Pakistan. 


\subsubsection{Hypotheses Construction}

To assess the research objective we have constructed the following hypotheses:

$\mathrm{H} 1$ : Export refinance scheme has relationship with export of medical instruments.

H2: Hydro electricity production has relationship with export of medical instruments.

H3: Interest rate has relationship with export of medical instruments.

H4: Dollar exchange rate has relationship with export of medical instruments.

H5: Steel wire prices have relationship with export of medical instruments.

H6: Gold prices have relationship with export of medical instruments.

\subsection{Methodology}

Study uses the time series monthly data for the sample period of fifteen years that is from FY 2003 to FY 2017. The study analysis applies the Johansen co-integration test for long run and applies the Vector Error Correction method for the short term relationship.

We emphasize on the significant relationship between operational/market risk and the exports of medical instruments by applying Johansen co-integration test and vector error model. The study analyze unit root presence by applying Augmented Dickey-Fuller test, optimal lags length by applying AIC support for five lags while SC and HQ support for one lag, Johansen co-integration test a strong long-run relationship between medical instruments export and independent variables and vector error correction model validity is also evident.

The following equations are representing the estimation model:

$$
\Delta \mathrm{Yt}=\beta 0+\sum_{\mathrm{i}=1}^{\mathrm{n}} \beta \mathrm{i} \Delta \mathrm{Yt}-\mathrm{i}+\sum_{\mathrm{i}=0}^{\mathrm{n}} \delta \mathrm{i} \Delta \mathrm{Xt}-\mathrm{i}+\varphi \mathrm{zt}-1+\mu \mathrm{t}
$$

$\mathrm{Z}$ is the ECT and is the OLS residuals from the long run Co-integration regression:

and can be defined as

$$
\mathrm{Yt}=\beta \mathrm{o}+\beta 1 \mathrm{Xt}+\varepsilon \mathrm{t}
$$

$$
\mathrm{zt}-1=\mathrm{ECTt}-1=\mathrm{yt}-1-\beta \mathrm{o}-\beta 1 \mathrm{Xt}-1
$$

\subsection{Variables Explanation}

There is one dependent variable and six independent variables:

Dependent Variable:

Export of medical instruments (LNMI) in US S in thousands

Independent Variables:

Government Refinance scheme (LNFIN) in US \$ in thousands

Hydro Power (LNHP) use as a proxy for operational risk and taken in billion Kilowatt Hours

Interest Rate (LNIR) return on government of Pakistan bonds in percentage use as proxy for market risk Dollar Exchange Rate (LNDR) PKR VS Dollar use as a proxy for market risk

Steel wire prices (LNSW) US \$ per Metric ton

Gold prices (LNGD) US \$ per troy ounce 
Table-2: Variable Explanation

\begin{tabular}{|l|l|l|l|l|l|}
\hline & Variable & Definition & Nature & Unitof Measurement & Frequency \\
\hline 1 & LNMI & $\begin{array}{l}\text { Medical instruments } \\
\text { export }\end{array}$ & Dependent & US thousand dollar & Monthly \\
\hline 2 & LNFIN & $\begin{array}{l}\text { Export refinance } \\
\text { scheme }\end{array}$ & Independent & US thousand dollar & Monthly \\
\hline 3 & LNHP & Hydel power & Independent & $\begin{array}{l}\text { Billion Kilowatt } \\
\text { Hours }\end{array}$ & Monthly \\
\hline 4 & LNIR & Interest rate & Independent & - & Monthly \\
\hline 5 & LNDR & Dollar exchange rate & Independent & Rupees per Dollar & Monthly \\
\hline 6 & LNSW & Steel wire price & Independent & Metric per ton & Monthly \\
\hline 7 & LNGD & Gold price & Independent & Per troy ounce & Monthly \\
\hline
\end{tabular}

\section{Results and Policy Inferences}

We start looking into the relationship of different variables with the export of medical instruments, the investigative results of independent variables show increasing trends over the study interval that is evident from the above figures. To further strengthen our findings, we applied Johansen co-integration test and Vector Error Correction Model.

The results of Johansen co-integration confirm that there is one co-integration equation in the model. The results are mentioned in table-3.

\section{Table-3: Johansen Co-integration Test}

\begin{tabular}{|c|c|c|c|c|c|c|}
\hline \multicolumn{7}{|c|}{ Unrestricted Co-integration Rank Test (Trace\& Maximum Eigen Value) } \\
\hline Hypothesized & & Trace & Max-Eigen & Trace & Max-Eigen & \\
\hline No. of CE(s) & Eigenvalue & Statistic & Statistic & Prob.** & Prob.** & \\
\hline None* & 0.378089 & 178.0341 & 64.59426 & 0.0000 & 0.0002 & \\
\hline At most 1 & 0.310297 & 113.4399 & 50.52322 & 0.0018 & 0.0024 & \\
\hline \multicolumn{7}{|c|}{$\begin{array}{l}\text { Trace test indicates } 1 \text { cointegratingeqn at the } 0.05 \text { level } \\
\text { Max-Eigen value test indicates } 1 \text { cointegratingeqn at the } 0.05 \text { level } \\
* \text { denotes rejection of the hypothesis at the } 0.05 \text { level } \\
\text { **MacKinnon-Haug-Michelis }(1999) \text { p-values - Lag interval } 1 \text { to } 1\end{array}$} \\
\hline
\end{tabular}

\subsection{Vector Error Correction Model (VECM)}

After confirming the co-integration among variables, Vector Error Correction Model is applied by using 1 lag over the time period 2003-2017. Table 4 exhibit result of Vector Error Correction Model, the results exhibit a direct positive relation of Hydro electricity generation and US\$ conversion in PKR with the export of medical instruments. The results are also supportive by earlier studies, a study (Bashir, Nasim and Ismail, 2016)argued that "electricity generation make sure proper running of factories and also support shut down units, however increment in production will lead to higher export of Pakistan". The results also support the argument that "higher electricity generation reduces the operational risk because of less electricity load shading". Further, the positive relation between US\$ conversion in PKR and export of medical instruments also theoretically support because this relation encourage exporter in order to have more local currency against the export. Whereas the value of error correction is negatively significant and indicate a long term relation between independent variables and the export of medical instruments with a deviation of one unit having a recovery of 2 months and 9 days. The new challenge for Pakistan can be considered for future study that is to analyze the influence of recent devaluation of PKR that can have 
dual influence on import of raw material and the export of finish goods. The results can be depicted from under mention table-4 and support our hypotheses.

Table-4: Vector Error Correction Model

\begin{tabular}{|c|c|c|c|c|c|c|c|}
\hline & $\begin{array}{l}\text { Short- } \\
\text { run } \\
\text { outcom } \\
\text { es }\end{array}$ & Long-rt & n outcom & & & & \\
\hline $\begin{array}{l}\text { Error } \\
\text { Correct } \\
\text { ion }\end{array}$ & $\Delta \mathrm{LNMI}$ & $\begin{array}{l}\text { LNFI } \\
\mathrm{N}\end{array}$ & LNHP & LNIR & LNDR & LNSW & LNGD \\
\hline $\begin{array}{l}\text { CointE } \\
\text { q1 }\end{array}$ & $\begin{array}{l}- \\
0.3440 \\
30 \\
{[-} \\
3.2876 \\
2]\end{array}$ & \multirow{7}{*}{$\begin{array}{l}0.0775 \\
11 \\
{[-} \\
0.9918 \\
7]\end{array}$} & \multirow{7}{*}{$\begin{array}{l}0.6604 \\
85 \\
{[-} \\
8.4927 \\
2]\end{array}$} & \multirow{7}{*}{\begin{tabular}{|l}
0.0545 \\
83 \\
{$[-$} \\
0.9108 \\
$7]$
\end{tabular}} & \multirow{7}{*}{$\begin{array}{l}0.8027 \\
59 \\
{[-} \\
5.1883 \\
0]\end{array}$} & \multirow{7}{*}{$\begin{array}{l}0.0407 \\
23 \\
{[-} \\
0.4291 \\
8]\end{array}$} & \multirow{7}{*}{$\begin{array}{l}- \\
0.0665 \\
11 \\
{[} \\
0.6371 \\
2]\end{array}$} \\
\hline $\begin{array}{l}\Delta \mathrm{LNFI} \\
\mathrm{N}\end{array}$ & $\begin{array}{l}- \\
0.0820 \\
43 \\
{[-} \\
0.9845 \\
3]\end{array}$ & & & & & & \\
\hline $\begin{array}{l}\Delta \mathrm{LNH} \\
\mathrm{P}\end{array}$ & $\begin{array}{l}0.1650 \\
21 \\
{[} \\
1.7659 \\
7]\end{array}$ & & & & & & \\
\hline$\Delta \mathrm{LNIR}$ & $\begin{array}{l}- \\
0.1174 \\
22 \\
{[-} \\
0.3824 \\
3]\end{array}$ & & & & & & \\
\hline $\begin{array}{l}\Delta \mathrm{LND} \\
\mathrm{R}\end{array}$ & $\begin{array}{l}- \\
1.1993 \\
97 \\
{[-} \\
1.2586 \\
0]\end{array}$ & & & & & & \\
\hline $\begin{array}{l}\Delta \mathrm{LNS} \\
\mathrm{W}\end{array}$ & $\begin{array}{l}0.2180 \\
96 \\
{[} \\
0.6880 \\
3]\end{array}$ & & & & & & \\
\hline $\begin{array}{l}\Delta \mathrm{LNG} \\
\mathrm{D}\end{array}$ & $\begin{array}{l}- \\
0.1780 \\
08 \\
{[-} \\
0.6255 \\
4]\end{array}$ & & & & & & \\
\hline
\end{tabular}




\section{T-Statistics in Brackets. Italic Coefficients are significant using lag order 1.}

\section{Conclusion}

Study initiate to examine the impact of market risk that include interest and exchange rate variation, operational risk that include hydro electricity production, prices variation of steel and gold due to different factors and government incentive schemes on the export of medical instruments by small and medium sector in Pakistan. Country export having its significance in terms of employment generation and economy restructuring, particularly SME sector play its vital role at grass root level. Study use export of medical instruments as dependent variable and export refinance scheme, hydro electricity production, interest rate, dollar exchange rate, steel price and the gold price as independent variables. The study analysis use Time series approach on monthly frequency fifteen years data from 2003 to 2017.

It was hypothesized that short run and long run relationship exist between the selected proxies for operational risk (hydro electricity production, Steel prices, gold prices and government incentive schemes) and market risk (interest rate, exchange rate variation), and export of the medical instruments.

The Johansen co-integration and Vector error correction model are used for analysis. The Johansen cointegration confirms long-run relationship between the export of medical instruments and independent variables and VEC model results exhibit a direct positive relation of Hydro electricity generation and US\$ conversion in PKR with the export of medical instruments. Further, the positive relation between US dollar conversion in PKR and export of medical instruments is also theoretically supported because this relation encourage exporter in order to have more local currency against the export. Whereas the value of error correction is negatively significant and indicate a long term relation between independent variables and the export of medical instruments with a deviation of one unit having a recovery of 2 months and 9 days.

\section{Limitations of the Study}

As about $90 \%$ of medical instruments export is from Punjab territory, therefore we only focus on export from Punjab and in case energy we solely focus on hydroelectricity generated by GEPCO to meet research requirement. These limitations do not affect the validity of the results.

\section{References}

Ahmad, I. (2015). 'The Value of Export Incentives'The Lahore Journal of Economics , 20(2), pp. 99-127.

Ali, M. Y. and Shamsuddoha, A. (2004). 'Direct and Indirect Impact of Export Promotion Programs on Export Performance'. Proceedings of the Australian and New Zealand Marketing Academy Conference, 29 November - 1 December 2004, Wellington, New Zealand.

Aqeel, A.,Nishat, M. (2006). 'The effect of exchange rate volatility on Pakistan exports'. Pakistan economic and social review, XLIV(1),pp 81-92.

Bashir, F., Nasim, I. and Ismail, A. (2016). 'Electricity Generation and Its Impact on Real GDP and Real Exports of Pakistan: A Co-integration Analysis', Journal of Management Sciences, 3(1), pp. 52-67.

Beck, T. (2007). 'Financing Constraints of SMEs in Developing Countries: Evidence, Determinants and Solutions', Financing Innovation-Oriented Businesses to Promote Entrepreneurship, pp. 1-35.

Bikker, J. A. and Vervliet, T. M. (2018). 'Bank profitability and risk-taking under low interest rates', International Journal of Finance \& Economics, 23(1), pp. 3-18. doi: 10.1002/ijfe.1595.

Enad, O.,Hasaballah,A.H.A.,Ibrahim,S.B., Elhag, A.(2017). 'Relationship between Export Promotion Programs and Export Performance: Does Perceived Usefulness Matter?',International Journal of Research. 6(1), pp.17071714 doi: 10.21275/ART20164490.

Fang, W., Lai, Y., and Miller, S.,M. (2006). 'Export Promotion through Exchange Rate Changes: Exchange Rate Depreciation or Stabilization'. Southern Economic Journal, 72(3), pp. 611-626.

Geldres-Weiss, V. V and Carrasco-Roa, J. A. (2016). 'Impact evaluation of national export promotion programs on 
export firms using contrast groups'. Int. J. Export Marketing, 1(1), pp. 77-89.

Haddoud, M. Y., Jones, P. and Newbery, R. (2017). 'Export promotion programmes and SMEs' performance: Exploring the network promotion role'. Journal of Small Business and Enterprise Development. , 24(1), pp. 68-87. doi: 10.1108/JSBED-07-2016-0116.

Haque, N. U. and Kemal, M. A. (2006) Impact of Export Subsidies on Pakistan's Exports. PIDE working Papers. Javid, A.Y.,Muhammad, J., Awan,Z.A. (2012). 'Electricity consumption and economic growth: evidence from Pakistan Electricity consumption and economic growth: evidence from Pakistan'. Economics and Business Letters, 1(3), pp. 16-27. Available at: http://mpra.ub.uni-muenchen.de/48011/

Karadag, D. H. (2016). 'The Role of SMEs and Entrepreneurship on Economic Growth in Emerging Economies within the Post-Crisis Era: an Analysis from Turkey'. Journal of Small Business and Entrepreneurship Development, 4(1), pp. 22-31. doi: 10.15640/jsbed.v4n1a3.

Kim-Soon, N., Ahmad, A. R. and Pei Shy, C. (2016). 'Export Promotion, Sales and Profits: A Structural Equation Modelling'. Journal of Southeast Asian Research, pp. 1-14. doi: 10.5171/2016.309540.

'Policy for Promotion of SME Finance State Bank of Pakistan' (2017), p. 9.

Saraç, T. B. and Karagöz, K. (2016). 'Impact of Short-term Interest Rate on Exchange Rate: The Case of Turkey'. Procedia Economics and Finance. 38. pp. 195-202. doi: 10.1016/S2212-5671(16)30190-3.

Shahbaz, M. (2015). Measuring Economic Cost of Electricity Shortage: Current Challenges and Future Prospects in Pakistan. Center for Energy Research, COMSATS Institute of Information Technology, Lahore, Pakistan, 002.

Small and Medium Enterprise Development Authority (SMEDA) (2017) 'Opportunities for SMEs under China Pakistan Economic Corridor ( CPEC ) An Exploratory Study'.

State Bank of Pakistan (2016). 'Prudential Regulations for Small \& Medium Enterprises Financing', Infrastructure, Housing \& SME Finance Department, pp. 13, 18.

Taiwo, M. D., Ayodeji, A. and Bako, Y. A. (2012). 'Impact of Small and Medium Enterprises on Economic Growth and Development'. American Journal of Business and Management. 1 (1). pp 18-22. doi: $10.11634 / 21679606170644$.

Wang, X., Chen, A. Wang, H., Li, S. (2017). 'Effect of export promotion programs on export performance: evidence from manufacturing SMEs'. Journal of Business Economics and Management. 18(1), pp. 131145. doi: 10.3846/16111699.2016.1278031.

Wang, Y. (2016). 'What are the biggest obstacles to the growth of SMEs in developing countries ? Bursa Istanbol Review. 16 (3), pp.167-176

Warren, G.F., Pearson, F. A. (2012). 'Relationship of Gold to Prices'. Journal of the American Statistical Association, pp. 118-126. 
